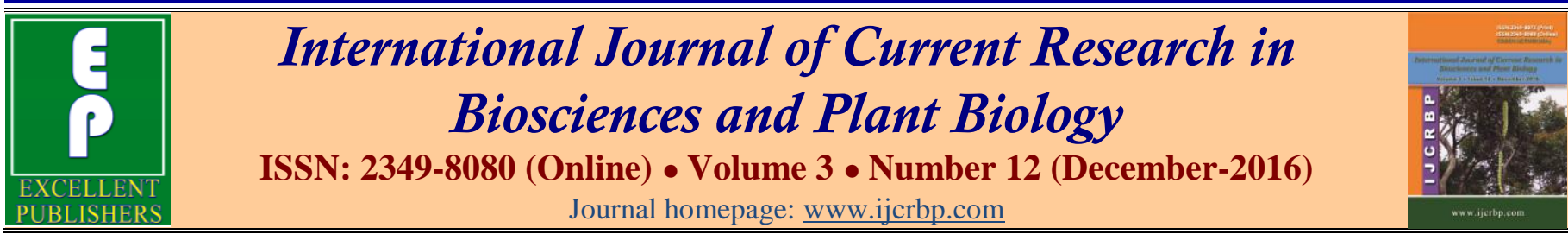

\title{
An Update on Checklist and Biodiversity of Coleopteran-fauna (Insecta) of Forestry and Mulberry Importance in Jammu and Kashmir State (India)
}

\section{Ramesh Chander Bhagat*}

P.O. Box No.125o, G.P.O., Residency Road, Srinagar, Kashmir-19o oo1, J \& K, India

*Corresponding author.

\section{A bstract}

The present paper deals with a total of 64 species of beetles and weevils (Coleoptera), belonging to 52 genera, under 14 families, associated with diverse species of forest and mulberry plantations, occurring in vast areas and localities of Jammu and Kashmir State. The Coleopteran species of forestry and mulberry importance accounts for 73.43 $\%$ and $35.93 \%$ respectively. The Coleopteran-fauna (47 spp.), spread over 12 families, is found to be infesting forest trees, viz. Ash, Benne, Birch, Conifers, Elms, Ivy, Maple, Oak, Parrotia, Plane tree, Poplars, Robinia, Salix, and Yew. Of these trees, Pines showed highest number of Coleopteran species i.e. 18, under 6 families, followed by Poplars, with 15 spp. (4 families) and Cedars, having 14 spp. (4 families) The Mulberry plantations (Morus spp.) both endemic as well as exotic, have been observed to be infesting 23 spp. of Coleopterans, distributed over 6 families. The Cerambycidae family is a dominant family, with $7 \mathrm{spp}$., associated with mulberry trees. This family in dominance is followed by Coccinellidae and Scarabaeidae, having 4 spp. each. An upto-date systematic faunal Checklist has been provided. Besides this, information on biodiversity has been given.
\end{abstract}

Article Info

Accepted: 29 November 2016 Available Online: 06 December 2016

\section{Keywords}

Biodiversity

Checklist

Coleopteran-fauna

Forest trees

Mulberry plantations

\section{Introduction}

In Jammu and Kashmir State, a total of 64 speciess of Cleopterans( beetles,weevils), under 14 families, is associated with diverse forest and mulberry trees in vast localities and areas of Jammu and Kashmir State. The various families of order Coleoptera of forestry and mulberry importance are: Anobiidae, Brentidae, Buprestidae, Cerambycidae, Chrysomelidae, Coccinellidae, Curculionidae, Elateridae, Monotomidae, Platypodidae, Scarabaeidae, Scolytidae, Scydamaenidae and Thanerocleridae. The larvae of Brentids, Buprestids, and Cerambycids bore tunnels into various parts and wood of the forest and mulberry trees, causing serious damage. The adults as well as the larvae of Chrysomelids feed on the leaves of forest and mulberry trees.In case of Curculionids, adults and larvae attack various parts of the forest trees (conifers). The adults of Elaterids are phytophagous and the larvae cause damage to dead tree.

The Scolytids and Platypodids, known as ambrosia or pin-and-shot hole borers. The representatives of these families bore small pin holes in wood of living, decayed trees, as well as timbers. These are regarded as serious insect pests of forestry plantations. The Coccinellids are associated with leaves of mulberry plantations in this 
region. The Scarabaeids cause heavy damage to foliage, flowers and roots of forest and mulberry trees, especially poplar nurseries in this region. The Anobiids, Scydamaenids and Thaneroclerid, damage dead wood and timber, are also associated with deep forest litter. The Monotomid beetle in this region, is associated with fallen and decayed forest trees.

\section{Materials and methods}

The database provided in this paper pertains to 64 Coleopteran species, under 14 families of diverse and economically important forest and mulberry trees, occurring in vast areas and localities of J \& K State. This State is located in northern part of the Indian subcontinent, in the vicinity of Karakorum and western Himalayan ranges. It is bounded by: Indian States, viz.Himachal Pradesh and Punjab; China and Chinaadministered part of Kashmir; Pakistan and Pakistanadministered portion of Kashmir.

Jammu and Kashmir State is divided into three geographically and climatically different Provinces, viz. Ladakh (cold desert), Kashmir (temperate) and Jammu (sub-tropical). This State is of paramount zoogeographical significance as well as rich in biodiversity.

In this paper, the Coleopteran-fauna of forestry and mulberry importance, has been updated in the light of latest nomenclatural/ systematic changes. In addition to this, host tree data has also been updated. For this purpose, relevant published works ( national and international), besides online data on taxonomic surveys and world systematic checklist/ catalogues have been consulted.

For updating the changes pertaining to systematics of taxa, the important monographs and online databases followed are: Anon. (2016a,b); Bright (2014); Danilevsky (2015); de Yong et al. (2014 ); Lobl and Smetana $(2010,2011)$ and, Wood and Bright (1992). The faunal records of valid Coleopteran species / genera, with host tree, are given in the Systematic Checklist. The synonyms of the taxa are listed under the valid species, given in the parentheses. The references pertaining to author(s) reporting and describing faunal taxa from different localities of $\mathbf{J} \&$ $\mathrm{K}$ State, are in the long brackets in front of each listed species. In addition to this, number of abbreviations with respect to host tree species are given in the Checklist. The key to the abbreviations, are cited at the end of this Checklist.

\section{Results and discussion}

\section{Systematic Checklist}

Family 1. Anobiidae (Death watch beetles

1. Gastrallus sp. [Khan et al., 2004]

Host: MP, MS

2. Lasioderma serricorne (Fabricius ) [Mahmood, 2004] Host: MP

3. Stegobium paniceum (Linnaeus) [Mahmood, 2004] Host: MP

Family 2. Brentidae (Straight snout weevil)

Subfamily: Apioninae

Tribe: Apionini

Subtribe: Apionina

4. Apion sp. [Azam, 2007; Tara et al., 2010]

Host: Q, QL, Se

Family 3. Buprestidae (Jewel beetles)

5. Chrysobothris femorata (Olivier) [Rishi, 1981]

Host: PE

6. Capnodis carbonariasexamaculata Ballion (=Capnodis kashmirensis Fairmaire) [Rishi, 1981] Host: PE

7. Sphenoptera aterrima Kerremans [Anon, 2005] Host: Pis

Family 4. Ceramycidae (Long-horn beetles)

Subfamily 1. Cerambycinae (Round-necked longhorns)

Tribe 1: Cerambycini

8. Aeolesthes sarta (Solsky) [Rishi, 1981; Bhat et al., 2010; Gaffar and Bhat, 1991]

Hosts: A, B, M, PA, PE, Pl, PN, Q, R, U

Tribe 2. Trachyderini

Subtribe 1: Trachyderina

9. Purpuricenus montanus White [Gahan, 1906;

Plavilstschikov, 1935]

(=Purpuricenus indus Semenov- Tian Shausk) [Rishi, 1981]

Hosts: Pci, PE

Subfamily 2. Lamiinae (Flat-faced longhorns)

Tribe 1. Acanthocininae

10. Rondibilis sp. [Bhat, 1987]

Host: MS

\section{Tribe 2. Batocerini}

11. Apriona cinerea (Chevrolat ) [Bhatia et al., 2007; Sharma and Bhatia, 1996; Singh and Prasad, 1985]

Host: Ps 
12. Apriona germari Stebbing [Anon, 1997; Hussain et al., 2007; Hussain and Bhuroo, 2012; Hussain and Chishti, 2010a, b; Khan et al., 2004]

Hosts: MP, MS

13. Batocera rufomaculata (DeGeer) [Anon, 1997; Hussain, 2008 (2009); Hussain and Chishti, 2010; Khan et al., 2004; Sharma and Tara, 1984, 1985a, 1985b; Zeya et al., 2003]

Host: MP, MS

Tribe 3. Onciderini

14. Onciderescingulata (Say) [Hussain, 2008 (2009)]

Host: MS

Tribe 4. Pteropliini

15. Sthenias grisator (Fabricius) [Khan et al., 2004; Zeya et al., 2003]

Host:MP, MS

16. Saperda (Sapreda) culcarata Say [Rishi, 1981]

Host: PS

Subfamily 3. Prioninae

Tribe: Prionoinae

17. Prionus (Neopolyarthron) imbricornis (Linnaeus)

(= Prionus imbricornis Linnaeus) [Hussain, 2008 (2009)]

Host: MS

Family 5. Chrysomelidae (Leaf-beetle)

1. Chrysomelinae(Broad-shouldered leaf-beetles )

Tribe: Chrysomelini

Subtribe: Chrysomelina

18. Chrysomela (Chrysomela) populi Linnaeus

( =Chrysomela populi Linnaeus) [Ahmad and Ashraf, 1981; Beeson, 1941]

Hosts: PA, PC, PD, PCi, PN, PR

19. Plagiodera versicolora (Laicharting) [Bhat, 1991]

Hosts: PS, PS

Subfamily 2. Eumolpinae (Oval-leaf beetle)

20. Bedelia sp. [Bhat, 1987]

Hosts; PS, SS

Subfamily 3. Galerucinae (Skeletonizing leaf-beetles)

Tribe 1. Alticini

21. Luperomorpha nigripennis Duvivier [Khan et al., 2004; Zeya et al., 2003]

Hosts: MP, MS

Subtribe: Alticina

22. Altica himensis Shukla [Khan et al., 2004; Zeya et al., 2003]

Hosts: MP, MS

23. Altica sp. [Pandey and Dwivedi, 2005; Pandey et al., 2007]

Hosts: PS, SS
Tribe 2. Galerucini

24. Mimastracynura Hope [Anon, 1997; Khan et al., 2004; Sharma and Tara, 1985a,b]

Host: MP, MS

Family 6: Coccinellidae

25 Coccinella undecipunctata Linnaeus [Khan and Nighat, 1991]

Host: MS

26. Halyziats chitcherini Semerov [Khan and Nighat, 1991; Illahi et al., 2011]

Host: MS

27. Oenopia conglobate (Linnaeua) [Khan and Nighat, 1991]

Host: MS

28. Propyleaquaturor decipunctata Linnaeus [Khan and Nighat, 1991]

Host: MS

Family 7. Curculionidae (True weevils)

Subfamily: Cryptorhynchinae

Tribe: Cryptorhynchini

Subtribe: Cryptorhynchina

29. CryptorhynchusrufescensRoelif [Anon, 2005]

Hosts: CD, PK, PiR, PiS

Family 8. Elateridae (Skipjacks, Clickbeetles, wire worms)

Subfamily Agrypninae

Tribe: Agrypnini

30 Lacon punctatus (Herbst) [Platia, 1985]

Hosts: Under bark of decayed tree trunk of forest trees (Conifers)

31. Lacon punctatus oblongus (Della- Beffa) [Platia, 1985]

Hosts: FT, Pis

Family 9. Monotomidae (Root-eating beetles)

Subfamily: Rhizophaginae

32. Rhizophagus pahalgamus Sen Gupta and Biswas [Sen Gupta and Biswas, 1977]

Hosts: Bark of the fallen forest trees

Family 10.Platypodidae (Ambrosia beetle)

Subfamily: Platypodinae

Tribe: Platypodini

33. Platypus inermis Sampson [Anon, 2005]

Hosts: CS, Pis 
Family 11Scarabaeidae (Scarabs)

Subfamily 1. Cetoniinae (Flower Chaffers)

Tribe 1: Cetoniini

Subtribe 1. Cetoniina

34. Protaetia (Potosia) impavida (Janson) [Rishi, 1981]

Host: Pn

Tribe 2. Gymnetini

Subtribe: Gymnetina

35. Cotinis nitida (Linnaeus) [Rishi, 1981]

Host: Pn

36. Oryctes nasicornis nasicornis (Linnaeus) [de Yong et al., 2014]

(= Oryctes nasicornis (Linnaeus) [ Rishi, 1981]

Hosts: Pn

37. Hilyotrogus holoscriceus (Redtenbacher) [Rishi, 1981; Hugel, 1848]

Hosts: Pn

38. Lepidiotabima culata (Saunders) [Sharma and Tara, 1985a,b]

Hosts: MS

39. Melolontha melolontha (Linnaeus) [Rishi, 1981]

Hosts: Pn

40. Schizonycha ruficollis (Fabricius) [Sharma and Tara, 1985a]

Host: MS

41. Holotrachia sp. [Sharma and Tara, 1985a]

Host: Ms

42. Maladera (Cephalocerica) insanabilis Breviska

[Sharma and Tara, 1985a]

Host: MS

Family 12.Scolytidae (Bark beetles)

Subfamily 1. Corthylinae

Tribe: Pityophthorini

43. Pityophthorus cedri (Wood) [Maiti and Sharma, 2009]

Hosts: CD, PG.

44. Pityophthorus coniferae Stebbing [Maiti and Saha, 2009]

Hosts: CD, PG

45. Pityophthorus deodara Stebbing [Maiti and Saha, 2009]

Hosts: AP, AW, CD, PiR, PW (= PiE)

Subfamily 2. Crypturginae

Tribe: Crypturgini

46. Crypturgus pusillus (Gyllenhall) [Bright, 2014;

Mifsud and Knizek, 2009]
(= Crypturgus cylindricollis Eggers) [Maiti and Saha, 2009]

Hosts: AS, CD, CL, PiS

Subfamily 3. Hylesininae

Tribe 1: Hylesinini

47. Hylesinus? Fraxinoides Schedl [Bright, 2014; de Lactos et al., 2004]

(Lepersisinus? fraxinoides Schedl [Schedl, 1957;

Beeson, 1961; Maiti and Saha, 2007)

Hosts: F

48. Polygraphus longifolia Stebbing [Anon, 2005]

Hosts: CT, Pis

49. Polygraphus major Stebbing [Bhat, 1987; Maiti and Saha, 2009]

Host: Pis

50. Polygraphus subopacus Thomson [Lobl and

Smetana, 2011]

(= Polygraphus minor Stebbing [Maiti and Saha, 2009]

Hosts: As, CD, PW (=PiE)

Subfamily 5: Ipinae

Tribe 1. Dryocoetini

51. Dryocoetes brownie Mandelshtam \& Petrov [Mandelshtam and Petrov, 2010a]

Host: FT

52. Drycoetes indicus Strohymeyer [Maiti and Saha, 2009]

Hosts: AW, PS (= PMO), PW (= PiE)

Tribe 2. Ipini

53. Ipsschmut zenhoferi Holzschuh [Maiti and Saha, 2009; Buhroo and Lakatosi, 2011]

Hosts: AW, CD, PG, PiS, PSS

54. Pityogenes spessivtsevi Lebedev [Maiti and Saha, 2009] Hosts: PiS, PSS

Tribe 3: Xyleborini

55. Xyleborinus saxesenii (Ratzeburg) [Anon, 1997; Dar et al., 2007; Lobl and Smetana, 2011; Wood and Bright, 1992]

(=Xyleborinus librocedri Swaini) [Maiti and Saha, 2009]

Hosts: MS, TT

Tribe 4: Scolytini

56. Pityogenes scitus Blandford [Bhat, 1987]

Host: PiS

57. Scolytus deodara (Stebbings) [Beeson, 1941; Maiti and Saha, 2009]

Hosts: CD, PW (= PiE)

58. Scolytus kashmirensis Schedl, 1958 [Khanday and Buhroo, 2015a; Maiti and Saha, 2009; Mandelshtam and Petrov, 2010]

Hosts: UV, UW 
59. ScolytusnitidusSchedl [Anon., 1997; Dar et al., 2001; Khanday and Buhroo, 2015b]

Host: Bu, MS

60. Scolytus stepheni Mandelshtam \& Petrov [Mandelshtam and Petrov, 2010b; Bright, 2014]

Host: UW

\section{Subfamily 7: Scolytoplatypodinae}

Tribe: Scolytoplatypodini

61. Scolytoplatypus daimio Blandford [Beaver and Gebhardt, 2006; Bright, 2014]

(= Scolytoplaypus kunala Strohmeyer [Maiti and Saha, 2009]

Hosts: AC, AS, CD, H, PJ, PSS, Q, T

62. Scolytoplatypus raja Blandford [Beaver and Gebhardt, 2006; Beeson, 1922]

(= Scolytoplatypus himalayensis Stebbings) [Maiti and Saha, 2009]

Hosts: Aca, C, PSS, Q

Family 13: Scydmaenidae (Scydmaenines / Ant-like Stone beetles)

Subfamily: Scydaeminae

Tribe: Cyrtoscydmini

63. Neuraphes (Pararaphes) aruensis Franz

[Jaloszynska, 2008]

(= Neuraphes (Pararaphes) kashmirensis Franz [Franz, 1979]

Hosts: Forest fallen/ rotten wood

\section{Family14: Thanerocleridae}

Subfamily:Thaneroderinae

64. Thaneroclerus quasitardatus Corporaal [Corporaal, 1939]

Hosts: PiE, UW

Key to the abbreviations, given in the Checklist:

A- Acer, AC- Acer caecium, Aca- Acacia, AP-Abies pindrow, $\mathrm{AS}=$ Abies species, $\mathrm{AW}=$ Abies webbiana, $\mathrm{B}=$ Betula, $\mathrm{BU}=$ Betula utilis, $\mathrm{C}=$ Cedrus, $\mathrm{CD}=$ Cedrus deodari, $\mathrm{CL}=$ Cedrus libani, $\mathrm{CS}=$ Cedrus spp., $\mathrm{CT}=$ Coniferous trees, $\mathrm{F}=$ Fraxinus, FDT= Forest decayed trees, $\mathrm{FT}=$ Forest trees. $\mathrm{H}=$ Hedra, $\mathrm{MP}=$ Mulberry plantation / cultivars (endemic, exotic), MS= Morus spp. (M.alba, M. nigra), $\mathrm{P}=$ Pinus, $\mathrm{PA}=$ Populus alba, $\mathrm{PC}=$ Populus casale, $\mathrm{PCi}=$ Populus ciliata, $\mathrm{PD}=$ Populus deltoidea, $\mathrm{PE}=$ Populus euphoritica?, $\mathrm{PG}=$ Pinus gerardiana, $\mathrm{PiE}=$ Pinus excelsa, $\mathrm{PiR}=$ Pinus roxburghii, $\mathrm{PiS}=$ Pinus spp., $\mathrm{PJ}=$ Parrotiopsis jacquemontiana (Decne), $\mathrm{PK}=$ Pinus kesiya, $\mathrm{Pl}=$ Platanus, $\mathrm{PMO}=$ Picea morinda, $\mathrm{PN}=$ Populus nigra, $\mathrm{Pn}=$ Poplar nurseries, $\mathrm{PR}=$
Populus robusta, $\mathrm{Ps}=$ Populus $\mathrm{sp} ., \mathrm{PS}=$ Picea smithiana, $\mathrm{PSS}=$ Picea spp., $\mathrm{PW}=$ Pinus wallichiana, $\mathrm{Q}=$ Quercus, $\mathrm{QL}=$ Quercus leucotrichophora, $\mathrm{R}=$ Robinia, $\mathrm{Se}=$ Sesamum, $\mathrm{SS}=$ Salix sp., $\mathrm{T}=$ Taxus. $\mathrm{TT}=$ Timber trees, $\mathrm{U}=$ Ulmus, $\mathrm{UV}=$ Ulmus vilosa, $\mathrm{UW}=$ Ulmus wallichiana .

\section{Diversity of Coleopteran-fauna affecting forest and mulberry trees}

From the above given Systematic Checklist, it is evident that in Jammu and Kashmir State, a total of 64 species of Coleopterans, under 52 genera, distributed over 14 families are associated with forest and mulberry trees, covering more than 14 plant families. The Copleopteran families of forestry and mulberry importance, each family with total number of species are: Anobiidae (3 spp.); Brenitidae (1); Buprestidae (3), Ceramycidae (10), Chrysomelidae (7); Coccinellidae (4); Curculionidae (1); Elateridae (2); Monotomidae (1); Platypodidae (1); Scarabaeidae (9); Scolytidae (20); Scydamaenidae (1) and Thanerocleridae (1). The previous checklists of pests of mulberry plantation, including beetles and weevils of Jammu and Kashmir State, have been provided by: Sharma and Tara (1985a,b); Sharma and Sharma (1989); Zeya et al. (2003) and Khan et al. (2004). Earlier Checklists of Coleopterans of Poplars of Kashmir are given by Rishi (1981) and, Ahmad and Faisal (2012).

A total of 23 species of Coleopterans, under 23 genera, distributed over 6 families are associated with mulberry plantations and the Coleoptera species, affecting trees of forestry importance include a total of $47 \mathrm{spp}$., under 38 genera, belonging to 12 families in $\mathrm{J} \& \mathrm{~K}$ State. The species infesting forest and mulberry trees, accounts for $73.43 \%$ and $35.93 \%$ respectively of the total species studies, known to be occurring in Jammu, Kashmir and Ladakh regions.

a) Conifers: The Conifers, belonging to family Pinaceae include forest trees of commercial importance such as Cedar (genus Cedrus), Firs (Abies), Pines (Pinus) and Spruce (Picea). The Pine species of J \& K State show association with highest number of Coleopteran species i.e. 18 , belonging to 6 families. The number of species in these families, viz. Buprestidae, Coccinellidae, Elateridae, Platypodidae, Scolytidae and Thanerocleridae, having 1 sp., 1 sp., 2 spp. 1 sp., 12 spp. and $1 \mathrm{sp}$. respectively. The highest Coleopteran species infestation in case of Pinus spp. of this region, is followed by Cedars, Firs and Spruce, with 14 spp., 8 spp. 
and 7 spp. respectively of Coleopterans, belonging to various families (see Table 1).

b) Poplars and Willow: The Poplars (Populus spp.) and Willows Salix spp.), belonging to family Salicaceae, cover about 7 spp. of Populus and 2 spp. of
Salix. The Populus spp. have been found to be associated with $15 \mathrm{spp}$. of Coleopterans of various families as: Buprestidae (2 spp.); Cerambycidae 4); Chrysomelidae (4) and Scolytidae (5). The willows (Salix spp.) have been found to be infested with 2 spp. of Chrysomelids (see Table 1).

Table1. Coleopteran families, with number of the species associated with the various families/genera/ species of the forest and mulberry trees of the Jammu and Kashmir State.

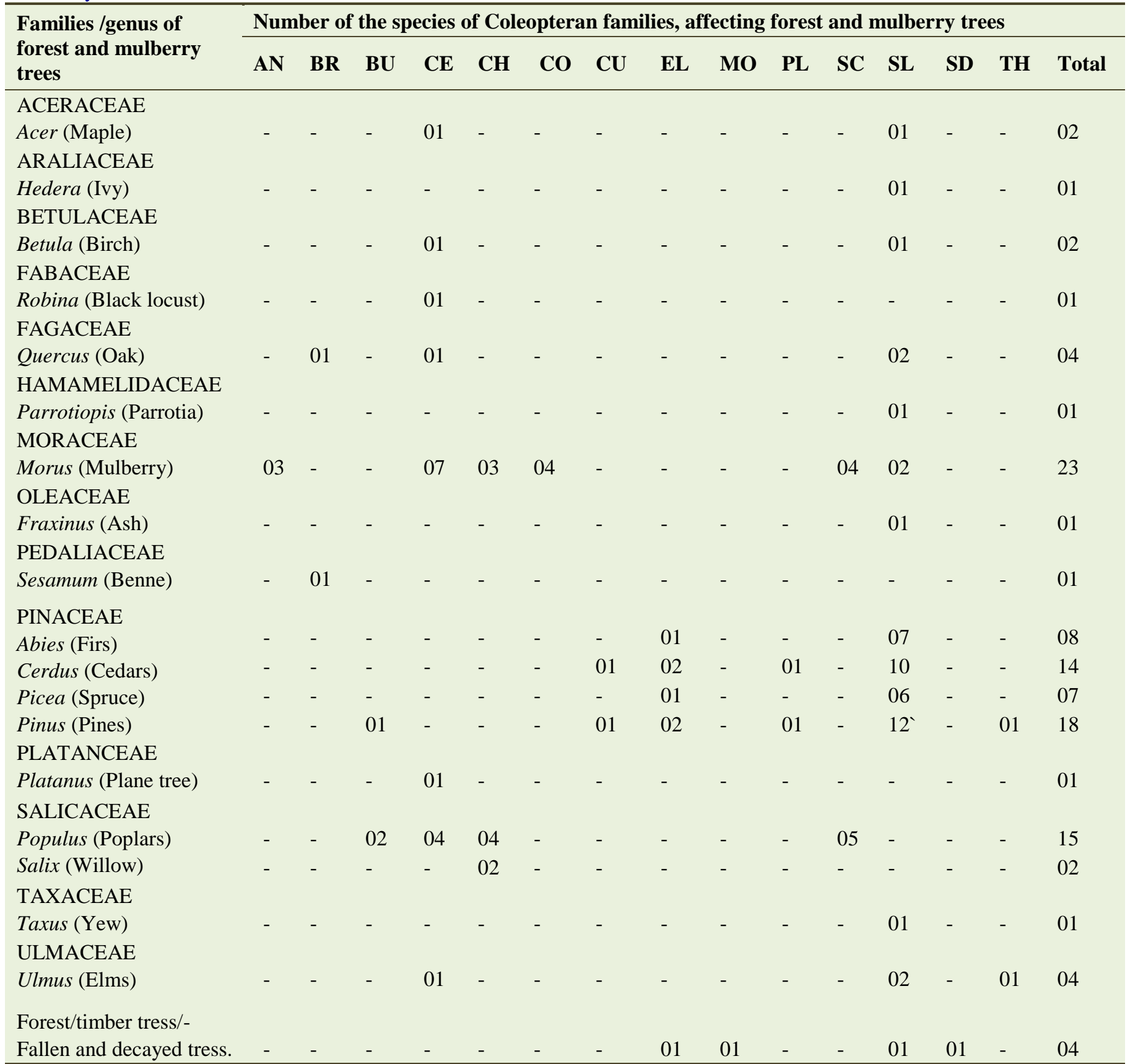

$\mathrm{AN}=$ Anobiidae; $\mathrm{BR}=$ Brentidae; $\mathrm{BU}=$ Buprestidae; $\mathrm{CE}=$ Cerambycidae; $\mathrm{CH}=$ Chrysomelidae; $\mathrm{CO}=\mathrm{Coccinellidae}$; $\mathrm{CU}=$ Curculionidae; $\mathrm{EL}=$ Elateridae; $\mathrm{MO}=$ Monotomidae; $\mathrm{PL}=$ Platypodidae; $\mathrm{SC}=$ Scarabaeidae; $\mathrm{SL}=\mathrm{Scolytidae}$; $\mathrm{SD}=$ Scydamaenidae; $\mathrm{TH}=$ Thanerocleridae. 
c) Other forest trees of economic importance: The economically important forest trees of $\mathrm{J} \& \mathrm{~K}$ State, viz. Black locust (Robinia), Fraxinus, Ivy, Parrotia, Platanus, Sesamum and Taxus, are observed to be infested with single species each of Coleopteran belonging to different families. The other important forest trees like Maple and Birch show association with 2 species each of Coleopterans. The highest number of species i.e. 4 each is seen infesting forest trees like Oaks and Elms (see Table 1 and Checklist).

d) Mulberry plantations: Of the total $64 \mathrm{spp}$. included in the present study, 23 species, under 23 genera, belonging to 6 families, were found to be associated with Morus spp. (Moraceae) (mulberry plantation / cultivars, exotic and endemic). The dominant family of Coleoptera of mulberry importance is known to be as Cerambycidae, having 7 spp. (7 genera), followed by Coccinellidae and Scarabaeidae with 4 spp. (4) each and, Anobiidae and Chrysomelidae, showing $3 \mathrm{spp}$. each. Besides these, 2 species pertaining to Scolytidae are also known to damage mulberry trees in J \& K State (see Checklist and Table 1).

\section{Conflict of interest statement}

Author declares that there is no conflict of interest.

\section{References}

Anonymous, 1997. Brief Report: Central Sericulture Research and Training Institute, Pampore (Central Silk Board) Ministry of Textiles, Govt. of India, Pampore, Kashmir.

Anonymous, 2005. Stocktaking of National Forest Invasive species Activities, -India, Country Report to Asia Pacific Invasive Species Network Asia Pacific Forestry Commission FAO Regional Office, Bangkok, Published by National Focal Point for APFISN, India, MOEF, Govt. of India, New Delhi.

Anonymous, 2016a. http//www.coleopsoc.org/buprestidae/ world cat (accessed 10.6.2016)

Anonymus, 2016b. http//www.insectoid.info/insect/neoptera (accessed 12.06.2016)

Ahmad, D., Aahraf, M, 1981.Notes on Biology and habits of Chrysomella populi L. (Col.: Chrysomelidae) in Forests of Kashmir. In: Proc. Symposium on Silviculture Management and Utilization of Poplars, Srinagar, 15-18 Oct.,1979. Govt. of India Press, Simla, India pp.142-143.

Ahmad, D., Ashraf, M,.,1982. The biology, damage and control of Chrysomela populi L. Coleoptera: Chrysomelidae ) infesting poplar nurseries in Kashmir. J. Environ. Res. 3 (1), 17-21.

Ahmad, M., Faisal, M.,2012. Status of Insect pests of Poplars in India, with special reference to Clostera spp. Forestry Bull. 12(1), 105-112.

Azam, M., 2007. Diversity, Distribution and abundance of weevils (Coleoptera: Curculionidae ) of Districts Poonch and Rajouri (Jammu). Ph.D. Thesis, University of Jammu.

Beaver, R.A., Gebhardt, H., 2006. A Review of the Oriental Species of Scolytoplatypus Schaufuss (Coleoptera, Curculionidae: Scolytinae). Mitt, Mus. Nat. Ko. Berl., Dtsch.Entomol.Z. 53, 155-178.

Beeson, C.F.C., 1922. The Food Plants of Indian Forest insects Part. VII (7) Scolytidae. Indian Forester. 47, 494-500.

Beeson, C.F.C., 1941. The Ecology and Control of the Forest Insects in Indian and the Neighbouring Countries. Vasant Press, Dehra Dun ii +1007 pp.

Bhat, M.A., Mantoo, M.A., Zaki, F.A., 2010. Management of tree trunk Borer, Aeolesthes sarta (Solsky) infesting apple in Kashmir. J. Insect Sci. 23(2), 124-128.

Bhat, M.R., 1987. Distribution and host range of some insect pests in Kashmir. Geobios New Rep. 6(2), 176-178.

Bhat, M.R., 1991. Distribution and host range of some insect pests in Kashmir. Geobios New Rep. 10, 160-161.

Bhatia, S., Sharma, B. Khajuria, 2007. Oviposition behaviour of stem borer, Apriona cinerea Chevrolat (Coleoptera: Cerambycidae) on poplars in Jammu Forests. In: Perspective in Animal Ecology and Reproduction. Vol.4. Daya Publishing House, New Delhi. pp.328-34.

Bright, Donald, E., 2014. A Catalogue of Scolytidae and Platypodidae (Coleoptera). Supplement 3 (2000-2012), with notes on subfamily and tribal reclassification. Insecta Mundi.0356, Paper 861. http: // digitalcommons.unl.edu/ insectmuni/861

Buhroo, A.A., Lakatos, F., 2011. Molecular and morphological diagnostic markers for the Himalayan Ips De Geer species (Coleoptera: Curculionidae). Zootaxa..3128, 47-57.

Corporaal, J.B., 1939. Revision of Thaneroclerinae (Cleridae, Col.). Bijdragen tot de Dierkunde. 27(1), 347-360.

Danilevsky, M.L., 2015. http://www.cerambycidae.net

Dar, G.H., Bhagat, R.C., Khan, M.A., 2002. Biodiversity of the Kashmir Himalaya. Valley Book House, Srinagar, Kashmir. 399p.

de Lactos, E., 2004. Les scolytes de corse (ColeopteraScolytidae) Le Coleopteriste. 7(3), 165-169.

de Yong, Y. et al., 2014. Fauna Europea all European animal species on the web. Biodiv. Data J. 2, e4034.doi:10:3897/ BDJ.2. e-4034.

Franz, H., 1979. Weitere Beitragezur Kenntnis der Scydmaeniden fauna dea Himalaya und Seiner Granzebiete. Entomol. Basiliensis. 4, 235-274.

Gaffar, S.H., Bhat, N.A., 1991. Management of stem borer, Aeolesthessarta (Solsky) infesting walnut tree in Kashmir. Indian J. Forestry. 14(14), 138-141.

Gahan, C.J., 1906. The Fauna of British India, including Ceylon and Burma- Coleoptera Cerambycidae, 329 pp.

Hugel, C.P. von, 1848. Kashmir und das Reich der Sick, 
Stuttgart, vol.4

Hussain, Altaf, 2008 (2009). Studies on the Bionomics and Integrated management of the Cerambycid borers of mulberry in Jammu and Kashmir State.Ph.D.Thesis, Faculty of Sciences, University of Kashmir, Srinagar, Kashmir.

Hussain, A., Buhroo, A.A., 2012. On the Biology of Aprionagermari Hope (Coleoptera: Cerambycidae), infesting mulberry plants in Jammu and Kashmir, India. Nature Sci. 10(1), 24-34.

Hussain, A., Chishti, M.Z., 2010a. Cerambycid borer infestations among different age group of mulberry, Morus spp. in Jammu and Kashmir. J. Himalayan Ecol. Sust. Dev. 5, 129-131.

Hussain, A., Chishti, M.Z., 2010b. Studies on the nature and extent of damage to mulberry plants by Apriona germari (Coleoptera: Cerambycidae). J. Res. Dev. 10, 143-150.

Hussain, A., Chishti, M.Z., Buhroo, A.A., Khan, M.A., 2007. Adult population of Apriona germari Hope (Coleoptera: Cerambycidae) in mulberry Farms of Jammu and Kashmir State (India). Pak. Entomol. 29(1), 15-17.

Hussain, A., Khan, M.A., Chishti, M.Z., Buhroo, A.A., 2009. Cerambycid borer of mulberry (Morus spp.). J. Appl. Pure Biol. 24(1), 101-103.

Illahi, I., Khan, M.A., Zeya, S.B., Aslam, M., Mittal, M., 2011. Feeding potential of mycophagous beetle, Halyziatschits cherini (Coleoptera, Coccinellidae) against powdery Mildew, Phyllactina corylea in Mulberry. Indian Phytopath. 64(2), 140-143.

Jaloszynski, P., 2008. Revision of Neuraphes Thomson of the Himalaya Mts. (Coleoptera: Scydmaenidae), Genus. 19(11), 619-637.

Khan, M.A., Dhar, A., Zeya, S.B., Trag, A.R., 2004. Pests and Diseases of Mulberry and their Control. Bishen Singh and Mahinder Pal Singh, Dehra Dun, India.

Khan, M.A., Nighat, 1991. Insect pest complex of mulberry (Morus spp.) in Kashmir. J. Tree Sci. 10(1),

Khandy, A.L., Buhroo, A.A., 2015a. Life history and biology of the Elm Bark beetle, Scolytus kashmirensis Schedl (Coleoptera: Curculionidae: Scolytinae) infesting Ulmus villosa in Kashmir. Open J. Forestry. 5, 443-453

Khandy, A.L., Buhroo, A.A., 2015b. Shot-hole borer (Coleoptera: Curculionidae: Scolytinae): A new hostHimalayan birch (Betula utilis). Nature Sci. 13(11), 87-89.

Lobl, I., Smetana, A. (Eds.), 2010. Catalogue of Palaearctic Coleoptera, Vol. 6. Chrysomeloidea. Stenstrup, Apollo Books. 924p.

Lobl, I., Smetana, A., 2011. Catalogue of Palaearctic Coleoptera Vol. 7 (Curculionoidea I) Apollo Books, 373p.

Mahmood, N., 2004. Record of two new insect pests of mulberry from Jammu and Kashmir State. Appl. Biol. Res. 6(1/2), 70.

Maiti, P.K., Saha, N., 2009. Fauna of India and Adjacent Countries- Scolytidae: Coleoptera (Bark and Ambrosia
Beetles). Vol. 1, Part 2, Published by Director, Zoological Survey of India, Kolkata. pp.1-245.

Mandelshtam, M.Y., Petrov, A., 2010a. Description of new Dryocoetes (Coleoptera, Curculionidae: Scolytinae) species from Afghanistan and Northern India and description of Scolytoplatypus kunala Strohn. Zookey. 56, 179-190.

Mandelshtam, M.Y., Petrov, V.A., 2010b. Scolytus stephensi sp. n.- A new species of bark beetle (Coleoptera: Curculionidae: Scolytinae) from Northern India, with a key to India Scolytus Geoffry, 1762 species. Zookeys. 56, 171-178.

Mifsud, D., Knizek, M., 2009. The bark beetles (Coleoptera: Scolytidae) of the Maltese Islands (Central Mediterranean). Bull. Entomol. Soc. Malta. 2, 25-52.

Pandey, A.K., Dwivedi, S.K., 2005. Insect pests and diseases of cold arid region, Ladakh. In: Crop Protection: Management Strategies (Ed.: Prasad, D.). Chapter 18. Daya Publishing House, New Delhi. pp. 276-287.

Pandey, A.K., Namgyal, D., Mir, M.S., Ahmed, S.B., 2007. Major insect pests associated with forest plantations in cold arid region, Ladakh of Jammu and Kashmir. J. Entomol. Res. 31(2), 155-162.

Platia, G., 1985. Descrizione di due nuove specie di Elateridae Palearctici (Coleoptera). Boll. Odella Soc. Entomol. Italiana. 117(4-7), 93-96.

Plavilstschikov, N. N., 1935. Notes sur Purpuricenus indus Sem. (Col., Cerambycidae). Stylops. IV(8), 189-191.

Rishi, N.D., 1981. Insect pests of Poplars in Kashmir Valley. In: Proc. Sym. Silviculture Management and Utilization of Poplars, held from 15-18 Oct. 1979. Govt. of India Press, Simla. pp.123-125.

Schedl, K.E., 1957. Indian bark and timber beetles. Indian Forest Rec. (N.S.). 9(8), 171-173.

Sengupta, T., Biswas, D.N., 1977. On the genus Rhizophagus Herbst. (Coleoptera, Rhizophagidae) and description of a new species. Rec. Zool. Surv. India. 72(1-2), 419-423.

Sharma, B., Bhatia, S., 1996. Management and control of Apriona cinera Chev. (Coleoptera, Cerambycidae). A stem borer of poplar in Jammu Forests. Indian Forester. 122, 383-385.

Sharma, B., Bhatia, S., 1989. Entomological Investigations done in India, along with a checklist of insect pests attacking mulberry plants in the world. The Jammu Univ. Rev. (Science). University of Jammu (J \& K). pp.183-193

Sharma, B., Tara, J.S., 1984. Studies on three mulberry varieties infected with Batocera rufomaculata) in Jammu Division, J \& K State. Zool. Orientalis. 1(1), 5-8.

Sharma, B., Tara, J.S., 1985a. Insect pests of mulberry plants (Morus) in Jammu region of Jammu \& Kashmir State. Indian J. Sericult. 24(1), 7-11.

Sharma, B., Tara, J.S., 1985b. Prevention and control of important insect pests of mulberry in Jammu ( $\&$ K $)$ State. Res. Dev. Reporter. 2(2), 72-74. 
Singh, P., Prasad, G., 1985. Poplar stem borer, Apriona cinerea Cheverolat (Coleoptera: Cerambycidae) its biology and control. Indian Forester. 111(7), 517-524.

Tara, J.S., Sharma, S., Kour, Ramnik, 2010. A record of weevil (Coleoptera: Curculionoidea) diversity from District Samba (J \& K). Bioscan. 5(3), 391-394.
Wood, S.L., Bright, D.E., 1992. A catalogue of Scolytidae and Platypodidae (Coleoptera), Part 2. Taxonomic Index, Vol. A. Great Basin Naturalist Mem. 13, 1-833 (A, B).

Zeya, S.B., Khan, M.A., Dhar, A., Mir, M.A., 2003. Insect pests of mulberry and their management in Jammu \& Kashmir-future strategies. Indian Silk. 41(9), 11-15.

\section{How to cite this article:}

Bhagat, R. C., 2016 An update on checklist and biodiversity of Coleopteran-fauna (Insecta) of forestry and mulberry importance in Jammu and Kashmir State (India). Int. J. Curr. Res. Biosci. Plant Biol. 3(12), 115123. doi: http://dx.doi.org/10.20546/ijcrbp.2016.312.014 